\title{
Wheat bran increases high-density-lipoprotein cholesterol in the rat
}

\author{
By N.-G. A SP \\ Department of Food Chemistry, Chemical Centre, University of Lund, Lund, Sweden
}

AND H. G. BAUER

Department of Surgery, University Hospital, Lund, Sweden

AND P. NILSSON-EHLE

Departmenı of Clinical Chemistry, University Hospital, Lund, Sweden

AND MARGARETA NYMAN AND R. ÖSTE

Department of Nutrition, Chemical Centre, University of Lund, Lund, Sweden

(Received 6 February 1981-Accepted 11 May 1981)

1. Five groups of male Sprague Dawley rats were given for 6 months a diet with high protein and fat contents but a very low dietary fibr z content (group B), and this diet mixed with $(\mathrm{g} / \mathrm{kg}$ ) 50 low-methoxyl pectin (group L), 50 high-methoxyl pectiı (group $\mathrm{H}$ ), 50 guar gum (group G) and 200 wheat bran (group WB, corresponding to 100 wheat fibre) respect ively.

2. The weight increment was significantly lower in group $G$ than in the other groups. Assuming no energy value of the dietary fibre, the weight increment $(/ \mathrm{kJ})$ was the same in groups $\mathrm{B}, \mathrm{L}$ and $\mathrm{H}$, lower in group $\mathrm{G}$ and higher in group WB, indicating that a proportion of the bran fibre might in fact be available as a source of energy.

3. Wheat bran increased total plasma cholesterol and high-density-lipoprotein cholesterol after 6, 12 and 26 weeks. Group $G$ had signi:icantly lowered plasma cholesterol after 12 weeks. Pectin on the other hand did not significantly influence total or HDL-cholesterol levels. It is therefore possible that the plasma cholesterol lowering effect of pectin previously rlemonstrated in the rat is dependent on the presence of significant amounts of dietary cholesterol as our diets did not contain added cholesterol. Plasma triglycerides decreased with age but were similar in all groups.

The hypothesis that dietary fibre may be a factor protecting against atherosclerotic diseases was introduced by Walker \& Arvidson (1954), and revived recently by Burkitt \& Trowell (1975). These authors considered the large amount of fibre in the diet of the African black as a main reason for the low incidence of coronary heart disease.

Experimental support for the hypothesis has been given by numerous experiments both in animals and man showing that certain gel-forming dietary fibre constituents, especially pectin and guar gum, significantly decreased plasma cholesterol concentrations. Studies with other types of fibre have shown varying effects on serum and liver cholesterol in experimental animals. Wheat bran has been tested in a large number of studies in man, all uniformly negative. Also in the cynomolgus monkey and the rat bran did not alter plasma lipids (Truswell \& Kíly, 1976; Kritchevsky, 1978).

Studies of experimental atherosclerosis have shown that it is difficult to induce vascular lesions with a fibre-ccntaining diet. Thus saturated fat has no atherogenic potential in the rabbit when added to a diet based on a laboratory ration. On the other hand atherosclerosis has been developed on semi-purified fibre-free diets with as little as $80 \mathrm{~g}$ saturated fat $/ \mathrm{kg}$. Wheat straw reduced the severity of atherosclerotic lesions in the rabbit despite its lack of effect on plasma cholesterol (Kritchevsky, 1978).

During the last decade, an increasing interest has focused on the differential atherogenic 
Table 1. Sources, composition ( $\mathrm{g} / \mathrm{kg}$ dry weight) of the dietary fibre preparations and composition of its neutral sugars and uronic acids

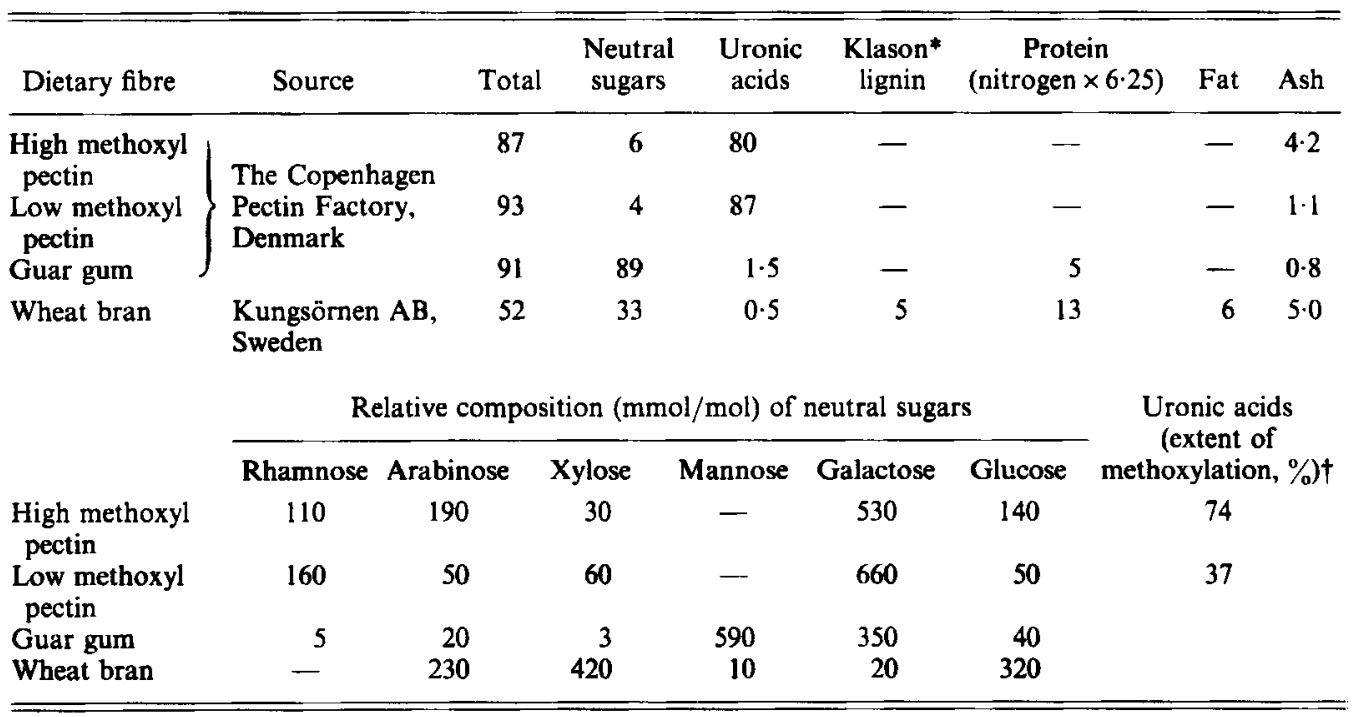

- Material insoluble in $72 \%$ sulphuric acid.

$\dagger$ Values from supplier, method according to food chemical codes.

potential of various lipoprotein classes; specifically the protective function of highdensity-lipoprotein (HDL) against atherosclerosis has been firmly established (Gordon et al. 1977). An assessment of plasma lipids as a risk factor for vascular disease therefore must include selective quantitation of lipoprotein classes.

With this background the present investigation was undertaken. Rats were given diets with two kinds of pectin, guar gum and wheat bran for 6 months and plasma triglycerides, and total and HDL cholesterol was measured after 6, 12 and 26 weeks. Effects of the fibres on food intake and efficiency were also studied.

\section{MATERIALS AND METHODS}

\section{Animals}

Male SPF Sprague-Dawley rats (Anticimex, Stockholm, Sweden), weighing approximately $135 \mathrm{~g}$ at the start of the experiment, were used. They were kept individually in steel-wire cages with free access to water and were adapted to a $12 \mathrm{~h}$ light and dark shift. The room was air-conditioned, maintained at $23^{\circ}$ and $50-60 \%$ relative humidity.

The different diets were fed ad lib. in metal containers designed to give minimal losses. The weight of the rats and the food consumption were registered weekly during the first 6 weeks and then every 2 weeks throughout the experiment.

\section{Diets}

A basal diet with high protein and high fat contents but very low in dietary fibre was prepared by mixing (g/kg) 200 casein (Kebo-Grave AB), 200 peanut oil (Karlshamns Oljefabriker AB), 100 sucrose (Svenska Socker AB), 441 wheat starch (AB Stadex), 50 mineral mixture (containing (g): $\mathrm{CuSO}_{4} .5 \mathrm{H}_{2} \mathrm{O} 8 \cdot 6, \mathrm{ZnSO}_{4} \cdot 7 \mathrm{H}_{2} \mathrm{O} 32 \cdot 0, \mathrm{KH}_{2} \mathrm{PO}_{4} 7780$, $\mathrm{NaH}_{2} \mathrm{PO}_{4} .2 \mathrm{H}_{2} \mathrm{O} 4024, \mathrm{CaCO}_{3} 7600, \mathrm{KI} 1 \cdot 6, \mathrm{MgSO}_{4} .7 \mathrm{H}_{2} \mathrm{O} 2000, \mathrm{FeSO}_{4} \cdot 7 \mathrm{H}_{2} \mathrm{O} 180$, $\mathrm{MnSO}_{4} \cdot \mathrm{H}_{2} \mathrm{O} 80, \mathrm{CoCl}_{2} 0.46, \mathrm{NaCl} 2382$ ), 8 vitamin mixture (containing (g): Menadione 
Table 2. Composition of experimental diets $(\mathrm{g} / \mathrm{kg} d r y$ weight)

\begin{tabular}{lcccccc}
\hline \hline Diet & Protein & Fat & Starch & Sucrose & Dietary fibre ${ }^{\prime}$ & Minerals \\
\hline Basal* $^{*}$ & 17 & 20 & 40 & 10 & - & 5 \\
High-methoxyl pectin & 16 & 19 & 38 & $9 \cdot 5$ & $4 \cdot 9$ & 5 \\
Low-methoxyl pectin & 16 & 19 & 38 & $9 \cdot 5$ & $5 \cdot 0$ & 5 \\
Guar gum & 16 & 19 & 38 & $9 \cdot 5$ & $5 \cdot 1$ & 5 \\
Wheat bran & 16 & 17 & 34 & 9 & $9 \cdot 8$ & 6 \\
\hline
\end{tabular}

* For details, see p. 386.

$\dagger$ Excluding the small proportion of undigestible starch that may contribute to total dietary fibre (similar in all groups).

$2 \cdot 5$, thiamin hydrochloride $10 \cdot 0$, riboflavin $10 \cdot 0$, pyridoxin hydrochloride $5 \cdot 0$, calcium pantothenate $25 \cdot 0$, nicotinic acid $25 \cdot 0$, folic acid $1 \cdot 0$, inositol $50 \cdot 0$, p-aminobenzoic acid $5 \cdot 0$, biotin $0.2 \mathrm{~g}$, vitamin $\mathrm{B}_{12}$, cyanocobalamin 0.015 , vitamin $\mathrm{A} 0.86$, vitamin $\mathrm{D} 0.025$, vitamin E 100, wheat starch 3765), 1 choline chloride (purchased through the hospital pharmacy). One group (B) of fifteen rats was given the basal diet.

The different fibre containing diets were prepared by mixing the basal diet with the dietary fibre preparations characterized in Table 1 . Thus group $\mathrm{H}$ was given the basal diet with high-methoxyl pectin (19:1, w/w; dry weight basis), group L the basal diet with low-methoxyl pectin $(19: 1, w / w)$, group $G$ the basal diet with guar gum $(19: 1, w / w)$ and group WB the basal diet with wheat bran $(4: 1, w / w)$. The composition of the diets is shown in Table 2 .

\section{Collection of faeces}

During $5 \mathrm{~d}$ of week 6 and week 12 faeces were collected from five rats in each group twice daily and frozen. They were then lyophilized and weighed.

\section{Blood sampling}

After 6,12 and 26 weeks, five rats in each group (four in groups L and WB after 26 weeks) were killed after $16 \mathrm{~h}$ fasting by carbon dioxide narcosis. Blood was withdrawn by cardiac puncture into tubes containing sodium EDTA as an anticoagulant.

\section{Analysis of dietary fibre}

Total dietary fibre including both water-soluble and water-insoluble components was analysed with an enzymic method, as described by Asp \& Johansson (1981). The dietary fibre was characterized by gas-liquid chromatographic assay of monosaccharides after acid-hydrolysis and gravimetric determination of lignin (Theander \& Åman, 1979). Uronic acids were assayed with a decarboxylation method (Bylund \& Donetzhuber, 1968) as modified by Theander \& Åman (1979).

\section{Analysis of plasma lipids}

HDL was separated by selective precipitation of very-low-density lipoprotein (VLDL) and low-density lipoproteir (LDL) by dextran sulphate and manganese chloride (Danielsson et al. 1978), and HDL cholesterol was measured by cholesterol determination of the clear supernatant fraction. (holesterol and triglycerides were analysed by enzymic procedures (Roeschlau et al. 1974; Wahlefeld, 1974). LDL-cholesterol concentrations were calculated according to the formula: LDL cholesterol = plasma cholesterol $-($ HDL cholesterol + plasma-triglyceride $\times 0.45$ ) (Friedewald et al. 1972). The plasma lipoprotein pattern was also monitored by agarose gel electrophoresis. 
Table 3. Weight development $(\mathrm{g})$ of rats given diets containing various kinds of dietary fibre

(Mean values and standard deviations)

\begin{tabular}{|c|c|c|c|c|c|c|c|c|c|c|}
\hline \multirow{2}{*}{$\begin{array}{l}\text { Diet } \\
\text { Week of } \\
\text { experiment }\end{array}$} & \multicolumn{2}{|c|}{ Basal } & \multicolumn{2}{|c|}{$\begin{array}{l}\text { High-methoxyl } \\
\text { pectin }\end{array}$} & \multicolumn{2}{|c|}{$\begin{array}{c}\text { Low-methoxyl } \\
\text { pectin }\end{array}$} & \multicolumn{2}{|c|}{ Guar gum } & \multicolumn{2}{|c|}{ Wheat bran } \\
\hline & Mean & $\mathbf{S D}$ & Mean & SD & Mean & SD & Mean & SD & Mean & SD \\
\hline $\begin{array}{l}\text { Start } \\
5 \\
11 \\
25\end{array}$ & $\begin{array}{l}135 \cdot 9 \\
323 \cdot 3 \\
412 \cdot 6 \\
488 \cdot 2\end{array}$ & $\begin{array}{r}4 \cdot 7 \\
20 \cdot 0 \\
23 \cdot 2 \\
25 \cdot 3\end{array}$ & $\begin{array}{l}133 \cdot 1 \\
319 \cdot 2 \\
417 \cdot 1 \\
470 \cdot 5\end{array}$ & $\begin{array}{r}6 \cdot 3 \\
18.9 \\
29.6 \\
34.4\end{array}$ & $\begin{array}{l}135 \cdot 0 \\
324 \cdot 4 \\
421 \cdot 5 \\
504 \cdot 4\end{array}$ & $\begin{array}{r}5 \cdot 4 \\
16 \cdot 1 \\
29 \cdot 6 \\
31 \cdot 0\end{array}$ & $\begin{array}{l}130 \cdot 1 \\
308 \cdot 5 \\
389 \cdot 9 \\
451 \cdot 1\end{array}$ & $\begin{array}{r}5 \cdot 2 \\
10 \cdot 7 \\
17 \cdot 2 \\
20.8\end{array}$ & $\begin{array}{l}133 \cdot 7 \\
329 \cdot 4 \\
429 \cdot 3 \\
477.6\end{array}$ & $\begin{array}{r}4 \cdot 9 \\
15 \cdot 3 \\
20 \cdot 5 \\
28 \cdot 9\end{array}$ \\
\hline
\end{tabular}

Table 4. Food intake of rats given diets containing various kinds of dietary fibre (cumulative intake; $g$ )

(Mean values and standard deviations)

\begin{tabular}{|c|c|c|c|c|c|c|c|c|c|c|}
\hline \multirow{2}{*}{$\begin{array}{l}\text { Diet } \\
\text { Week of } \\
\text { experiment }\end{array}$} & \multicolumn{2}{|c|}{ Basal } & \multicolumn{2}{|c|}{$\begin{array}{c}\text { High-methoxyl } \\
\text { pectin }\end{array}$} & \multicolumn{2}{|c|}{$\begin{array}{c}\text { Low-methoxyl } \\
\text { pectin }\end{array}$} & \multicolumn{2}{|c|}{ Guar gum } & \multicolumn{2}{|c|}{ Wheat bran } \\
\hline & Mean & SD & Mean & SD & Mean & SD & Mean & SD & Mean & SD \\
\hline $\begin{array}{r}5 \\
11 \\
25\end{array}$ & $\begin{array}{r}510.7 \\
1068.4 \\
2490.8\end{array}$ & $\begin{array}{l}31 \cdot 5 \\
69 \cdot 1 \\
52 \cdot 1\end{array}$ & $\begin{array}{r}529 \cdot 2 \\
1130 \cdot 1 \\
2462 \cdot 6\end{array}$ & $\begin{array}{l}32 \cdot 6 \\
60 \cdot 0 \\
85 \cdot 4\end{array}$ & $\begin{array}{r}535.7 \\
1145 \cdot 2 \\
2678.9\end{array}$ & $\begin{array}{l}35 \cdot 1 \\
86 \cdot 5 \\
91 \cdot 7\end{array}$ & $\begin{array}{r}551 \cdot 5 \\
1120 \cdot 3 \\
2445 \cdot 6\end{array}$ & $\begin{array}{l}26 \cdot 2 \\
50 \cdot 2 \\
38.9\end{array}$ & $\begin{array}{r}572.0 \\
1228.4 \\
2686.6\end{array}$ & $\begin{array}{l}25 \cdot 8 \\
52 \cdot 1 \\
19 \cdot 1\end{array}$ \\
\hline
\end{tabular}

\section{Statistical evaluation}

Student's $t$ test (two-tailed) was used for weights of rats, faeces and food intake. Differences in plasma lipid and lipoprotein concentration were evaluated with Wilcoxon's test (two-tailed).

\section{RESULTS}

Food intake and weight development

As shown in Table 3, the weight development was very similar in the groups given the basal diet (group B) and diets containing the pectins and wheat bran (groups H, L and WB) but consistently lower in the group given guar gum (G). Both at 5 and 11 weeks the weight increase in group WB was significantly higher than in group $\mathrm{G}(P<0.05$ and $P<0.001$ respectively). At 11 weeks the difference between group $\mathrm{G}$ and the other three groups also reached statistical significance $(P<0.05)$.

The food intake was higher in all groups given the fibre-containing diets. The mean exceeded that of group B with $4-5 \%$ in groups $\mathrm{H}$ and $\mathrm{L}, 8 \%$ in group $\mathrm{G}$ and $12 \%$ in group WB (Table 4). The weight increase/g food intake after 5 weeks is shown in Fig. 1(a). It was significantly lower in the guar gum and wheat bran groups than the controls.

The energy content of the different diets was calculated assuming no energy value of the dietary fibre. Using the conversion factors $17 \mathrm{~kJ} / \mathrm{g}$ protein and carbohydrate and $39 \mathrm{~kJ} / \mathrm{g}$ fat the following values $(\mathrm{kJ} / \mathrm{g})$ were obtained: diet $\mathrm{B} 19 \cdot 6$, diets $\mathrm{H}, \mathrm{L}$ and $\mathrm{G} 18 \cdot 6$, diet WB 17.2. Calculation of the weight increment $/ \mathrm{kJ}$ gave almost identical values for diets $B, H$ and $L$, a significantly lower value for diet $G$ and a significantly higher value for diet WB as shown in Fig. 1(b). 

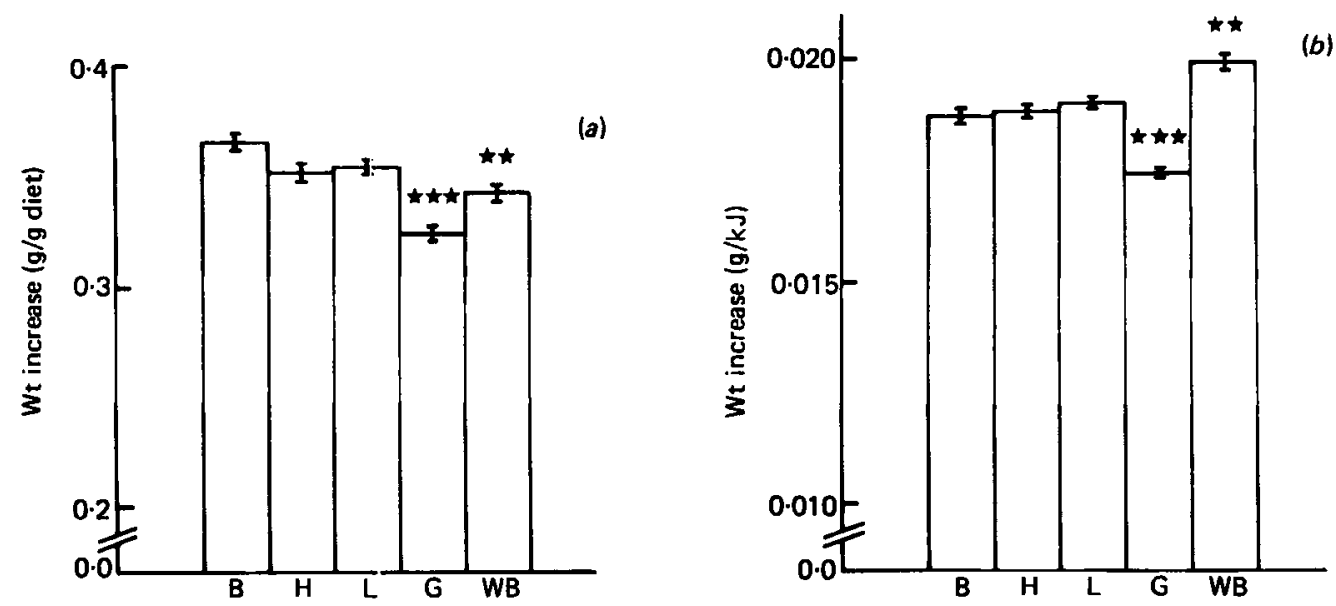

Fig. 1. Weight increment on $(a) / g$ diet basis and $(b) / \mathrm{KJ}$ assuming no energy value of dietary fibre in rats given diets containing different dietary fibres. Group B, basal diet; group $\mathrm{H}$, high-methoxyl pectin diet; group L, low-methoxyl pectin diet; group G, guar gum diet; group WB, wheat bran diet. Mean values are given with their standard errors represented by vertical bars. ${ }^{* *} P<0.01,{ }^{* * *} P<0.001$.

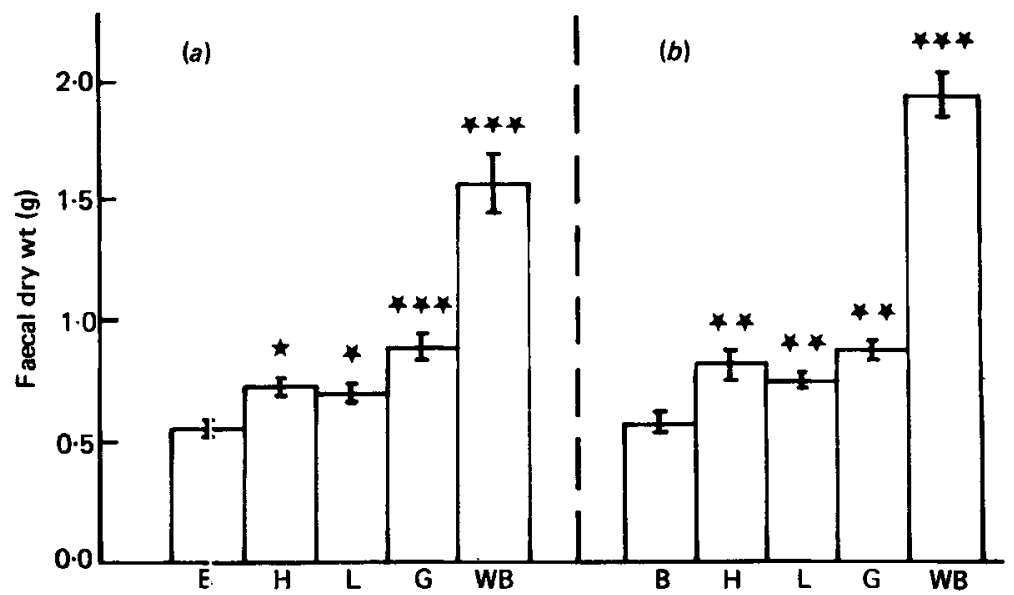

Fig. 2. Faecal dry weights after 6 weeks $(a)$ and 12 weeks $(b)$ in rats given diets containing different dietary fibres. Group B, basal diet; group H, high-methoxyl pectin diet; group L, low-methoxyl pectin diet; group $G$, guar gum diet; group WB, wheat bran diet. Mean values are given with their standard errors represented by vertical bars. $* P<0.05, * * P<0.01, * * * P<0.001$.

\section{Faecal bulking}

As shown in Fig. 2 the two kinds of pectin and guar gum gave slight but significant increases of faecal dry weight. Wheat bran gave a threefold increase.

\section{Plasma lipids}

Total plasma cholesterol was significantly elevated in group WB after 6,12 and 26 weeks. After 12 weeks there 'was a significant reduction in group G (Fig. 3).

Quantitative analys s of individual lipoprotein classes demonstrated that the differences in plasma cholesterol le:vels could be essentially accounted for by changes in HDL-cholesterol concentrations which were significantly elevated at all time-points in group WB. A slight but statistically significant decrease could be demonstrated in group $G$ after 12 and 26 weeks (Fig. 4). The increased HDL concentrations were also evident from visual inspection of the 


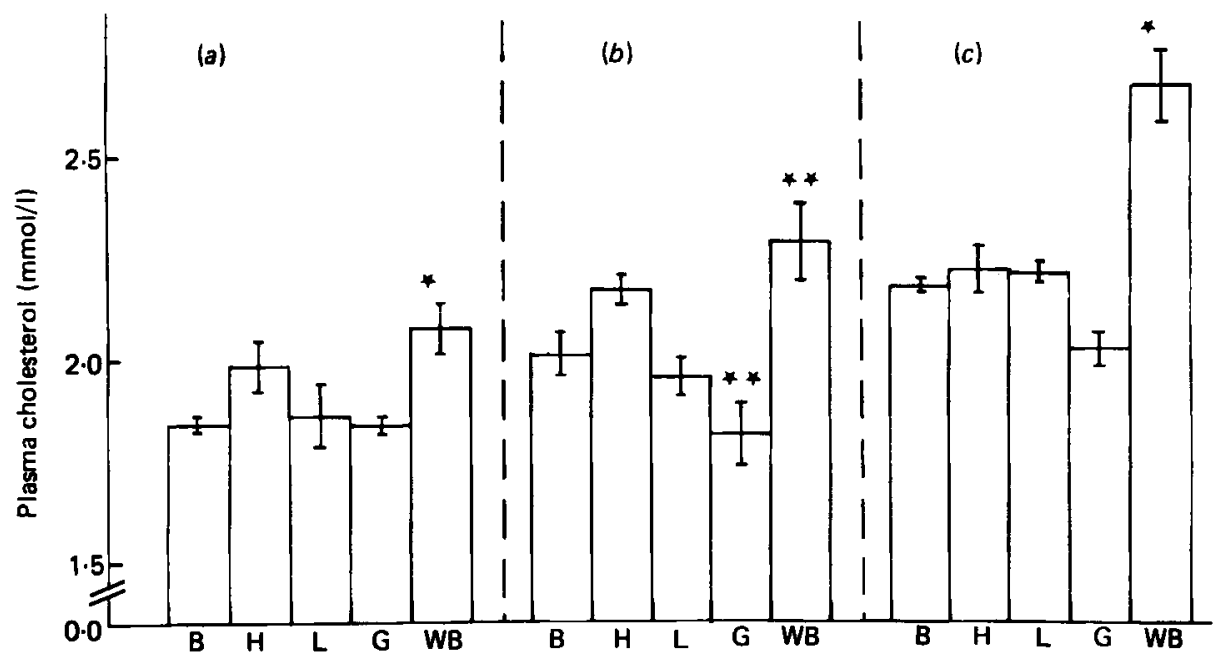

Fig. 3. Total plasma cholesterol after $6(a), 12(b)$ and $26(c)$ weeks in rats given diets containing different dietary fibres. Group B, basal diet; group H, high-methoxyl pectin diet; group L, low-methoxyl pectin diet; group G, guar gum diet; group WB, wheat bran diet. Mean values are given with their standard errors represented by vertical bars. ${ }^{*} P<0.05$, ${ }^{* *} P<0.01$.

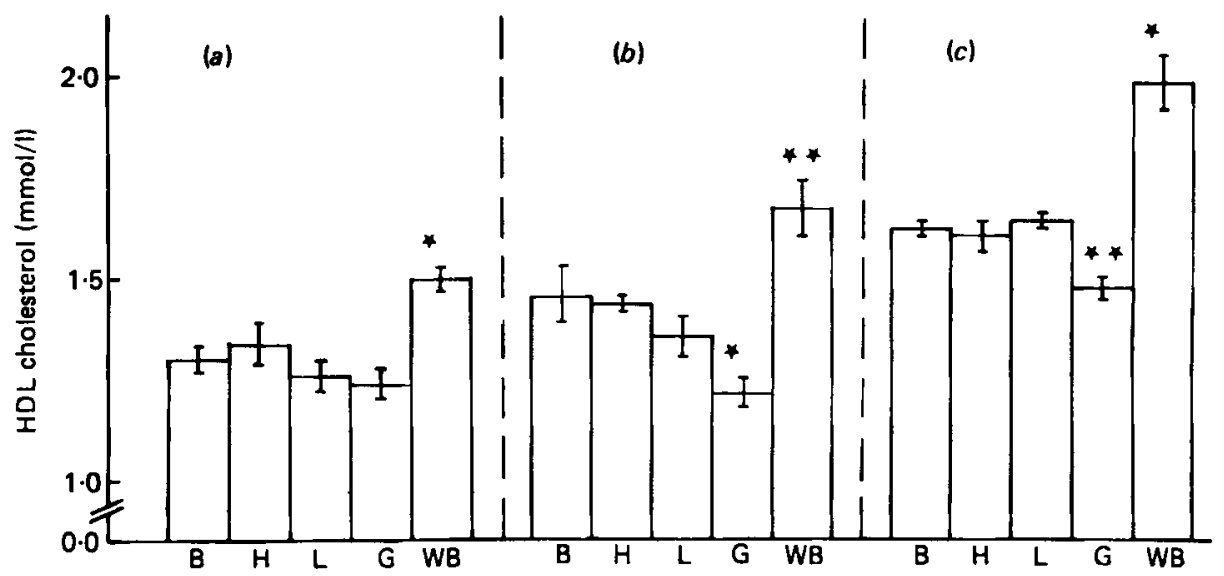

Fig. 4. High-density-lipoprotein cholesterol after $6(a), 12(b)$ and $26(c)$ weeks in rats given diets containing different dietary fibres. Group B, basal diet; group $\mathbf{H}$, high-methoxyl pectin diet; group L, low-methoxyl pectin diet; group G, guar gum diet; group WB, wheat bran diet. Mean values are given with their standard errors represented by vertical bars. $P<0.05,{ }^{* *} P<0.01$.

intensity of the $\alpha$-lipoprotein band after gel electrophoresis. LDL-cholesterol levels, which are comparatively very low $(0.2-0.4 \mathrm{mmol} / \mathrm{l})$ in the rat, were similar in all the groups, (results not shown in Fig. 4).

Plasma triglycerides (Fig. 5) decreased with age but were similar in all groups, except for a slight temporary elevation in group $\mathrm{G}$ after 6 weeks. On gel electrophoresis, no chylomicrons were demonstrable, indicating that plasma triglyceride concentrations essentially corresponded to VLDL concentrations. 


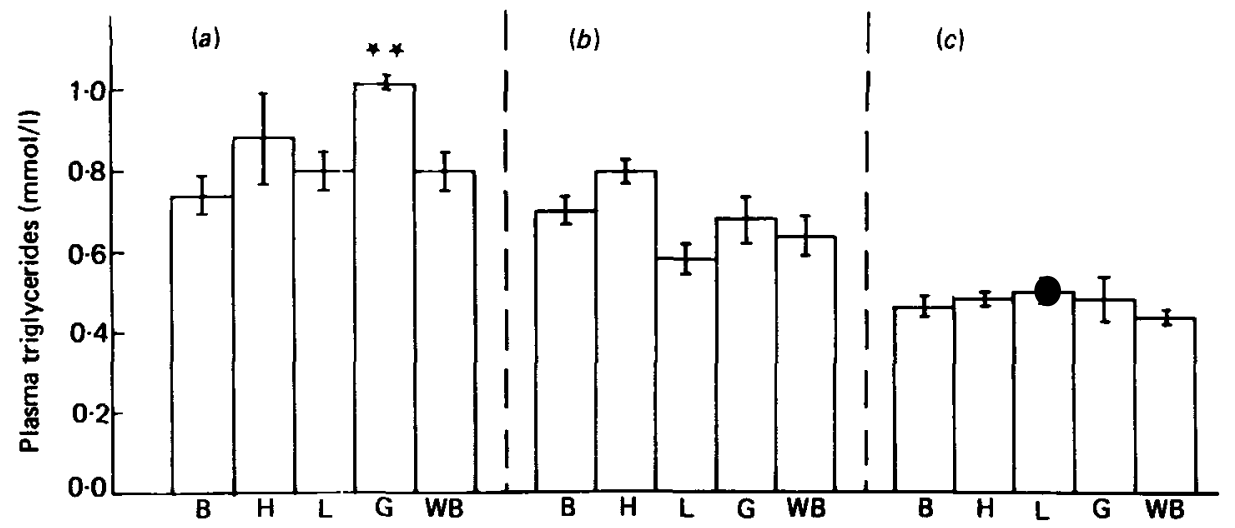

Fig. 5. Plasma triglycerides after $6(a), 12(b)$ and $26(c)$ weeks in rats given diets containing different dietary fibres. Group B, basal diet; group H, high-methoxyl pectin diet; group L, low-methoxyl pectin diet; group G, guar gurn diet; group WB, wheat bran diet. Mean values are given with their standard errors represented by vertical bars. ** $P<0.01$.

\section{DISCUSSION}

A plasma cholesterol-lowering effect of pectin and guar gum is documented in many studies both in man and in experimental animals (Truswell \& Kay, 1976; Kritchevsky, 1978). Some trials indicate that in man LDL cholesterol is specifically reduced (Tuomilehto et al. 1979). Cereal fibre in the form of wheat bran is the most extensively studied type of dietary fibre. Although at least ten human studies of effects on total plasma cholesterol have been uniformly negative, two brief reports (Bremner et al. 1975; O'Moore et al. 1978) indicate that bran might increase HDL cholesterol in man. In the present study therefore pectin, guar gum and wheat tran were chosen as sources of dietary fibre.

Naturally-occurring pectins differ in the extent of methoxylation, i.e. methanol esterification of the galacturonic acid carboxyl residues. This can be expected to influence considerably the interaction of pectin with other substances in the gastrointestinal tract and thereby its physiological effects. Two well-defined pectin preparations with low and high extents of methoxylation respectively were therefore used (Table 1). The amount of both pectin and guar gum in the diets was approximately $50 \mathrm{~g} / \mathrm{kg}$, which would correspond to $20-25 \mathrm{~g} / \mathrm{d}$ in a human diet, i.e. a level commonly used in studies of effects on plasma lipids and glucose tolerance (Jenkins $e t$ al. 1976). It is hardly possible, however, to reach similar amounts of pectin or guar gum in natural diets even if they are very rich in fruit and vegetables. In a recent study on the dietary intake of vegans with the duplicate-portion technique (Abdulla et al. 1981) we found a mean total dietary fibre intake of $6.9 \mathrm{~g} / \mathrm{MJ}$ or $43-62 \mathrm{~g} / \mathrm{d}$. Similarly, the amounts of wheat bran used $(200 \mathrm{~g} / \mathrm{kg}$, giving approximately $100 \mathrm{~g}$ cereal fibre $/ \mathrm{kg}$ ) $2 . r e$ larger than those found in natural diets, corresponding to a daily intake of $40-50 \mathrm{~g}$ fibre or $500-600 \mathrm{~g}$ whole-grain bread in man.

Pectin or bran did not alter the growth of the rats (Table 3). The food intake, however, increased roughly proportionally to the dietary fibre content (Table 4). Calculation of weight increase per unit energy intake, assuming no energy value of the dietary fibre, gave identical values for the pectin groups (groups $\mathrm{L}$ and $\mathrm{H}$ ) and the group B (basal-diet group), showing that the pectin did not interfere with the utilization of energy-generating nutrients. This calculation also supports the concept that pectin has no energy value, despite the fact that it is extensively metabclized by the colonic flora. In our experiment the mean intake of pectin in groups $\mathrm{L}$ and $\mathrm{H}$ was approximately $0.7 \mathrm{~g} / \mathrm{d}$ and the increase in faecal dry weight only approximately $0.2 \mathrm{~g} / \mathrm{d}$, showing that at least $70 \%$ had been metabolized (Fig. 2). 
The group given wheat bran (group WB) had a significantly larger weight increase per unit energy intake than the group $B$, indicating that a proportion of the wheat fibre might be available as a source of energy, presumably through colonic absorption of microbial breakdown products. Obviously, the prominent faecal bulking (Fig. 2) did not decrease energy utilization.

Group G (basal diet + guar gum) had a lower weight increment than group B despite an $8 \%$ increase in food intake (Table 4). This could not be explained by faecal losses, since the faecal dry weight increased only approximately $0.3 \mathrm{~g} / \mathrm{d}$, most of which can be expected to represent undegraded guar gum (Harmuth-Hoene $e t$ al. 1978). In search of an explanation for this interference with energy utilization (protein is certainly not a limiting factor in these diets) it is interesting to recall the investigation of Bachmann et al. (1978) showing an uncoupling of oxidative phosphorylation in liver and heart mitochondria of rats given small doses of gum arabic, gum tragacanth, methylcellulose and carboxymethyl cellulose. Also in man, guar gum seems to be effective in reducing body-weight (Tuomilehto et al. 1979).

The only consistent effect of the dietary fibre on plasma lipid and lipoprotein patterns was a significant elevation in HDL concentrations in the rats eating wheat bran. A 20-25\% increase was obvious after 6 weeks on this diet and persisted throughout the study. Since HDL carry a substantial proportion of the total plasma cholesterol in the rat, the increase in HDL cholesterol will also be associated with a similar elevation in total plasma cholesterol concentrations. The increase of HDL cholesterol in the rats fed on bran is in agreement with the recent preliminary reports of a similar effect in man. However, since HDL cholesterol represents a much smaller proportion of the total plasma cholesterol in man than in the rat (20-30\% compared to $70-80 \%)$, the elevation of HDL cholesterol in man is not necessarily reflected in significant alterations in plasma cholesterol levels (Bremner et al. 1975; O'Moore et al. 1978). Measurements of individual lipoprotein classes, thus, is a prerequisite for monitoring the effects of different diets on lipid metabolism. The bran-induced increase in HDL levels is interesting in relation to the finding of Morris $e t$ al. (1977) that a high cereal fibre intake in British middle-aged men was correlated with a low incidence of coronary heart disease.

The present study is only descriptive and gives little support for speculations on the mechanisms behind the increased HDL concentrations in the group given wheat bran. Plasma HDL are formed partly from hepatogenic 'nascent' HDL particles and partly from the hepatogenic and intestinal triglyceride-rich lipoproteins (VLDL and chylomicrons), the surface film of which is transferred to the HDL class during the lipolytic breakdown of the triglyceride core (Nilsson-Ehle et al. 1980). Alterations in the flux of triglyceride-rich particles can thus be expected to result in changes in plasma HDL concentrations. However, since the fat content of the wheat-bran-containing diet was slightly lower than that of the other diets, an increased production and turnover of chylomicrons in this group seems highly unlikely as an explanation for the elevated HDL levels.

Pectin did not alter plasma lipid or lipoprotein concentrations in the present investigation. This is in contrast to earlier reports, generally showing a decrease of total serum cholesterol by $10-20 \%$ when feeding $25-100 \mathrm{~g}$ pectin $/ \mathrm{kg}$. Of ten rat studies reviewed by Kritchevsky (1978) only two were negative. All these studies, however, were performed with 5-10 g cholesterol $/ \mathrm{kg}$ in the diet, whereas our diets did not contain cholesterol.

Thus, the earlier reported cholesterol-lowering effect of pectin is probably related to an interference with the absorption of dietary cholesterol. Guar gum on the other hand seemed to have a slightly lowering effect of both total and HDL cholesterol also in cholesterol-free diet.

The investigation was supported by the Swedish Medical Research Council (13x-4966, 03x-4745), the Swedish Nutrition Foundation and Påhlssons Foundation. 


\section{ADDENDUM}

In an extended study just finished, a lower concentration of wheat bran $(100 \mathrm{~g} / \mathrm{kg}$ corresponding to about $50 \mathrm{~g}$ wheat fibre $/ \mathrm{kg}$ ) also gave a significant although less prominent HDL cholesterol elevation. Furthermore, pectin $(50 \mathrm{~g} / \mathrm{kg})$ added to diets containing cholesterol $(5 \mathrm{~g} / \mathrm{kg})$ lowered both total plasma cholesterol and HDL cholesterol.

\section{REFEREN CES}

Abdulla, M., Andersson, I., Asp, N-G., Berthelsen, K., Birkhed, D., Dencker, I., Johansson, C-G., Jägerstad, M., Kolar, K., Nair, B., : Vilsson-Ehle, P., Nordén, A., Rassner, S., Åkesson, B. \& Öckerman, P-A. (1981). Am. $J$. clin. Nutr. (In the Prets).

Asp, N-G. \& Johansson, C-G. (1981). In Analysis of Dietary Fiber in Human Foods, p. 173 [W. P. T. James and O. Theander, editors]. New York: Marcel \& Dekker.

Bachmann, E., Weber, E., Post, M. \& Zbinden, G. (1978). Pharmacology. 17, 39.

Bremner, W. F., Brooks, P. M., Third, J. L. H. C. \& Lawrie, T. D. V. (1975). Br. med. J. ii, 574.

Burkitt, D. P. \& Trowell, H. C. (1975). Refined Carbohydrate Foods and Disease. London: Academic Press.

Bylund, M. \& Donetzhuber, A. (1968). Sv. Papperstidn. 15, 505.

Danielsson, B., Ekman, R., Fex, G., Johansson, B. G., Kristensson, H., Nilsson-Ehle, P. \& Wadstein, J. (1978). Scand. J. clin. Lab. Invest. 38, 113.

Friedewald, W. T., Levy, R.. I. \& Fredrickson, D. S. (1972). Clin. Chem. 18, 499.

Gordon, T., Castelli, W. P., Hjortland, M. C., Karmel, M. B. \& Dawber, T. R. (1977). Am. J. Med. $62,707$.

Harmuth-Hoene, A. E., Jalcubick, W. R. \& Schelenz, R. (1978). Nutr. Metab. 22, 32.

Jenkins, D. J. A., Leeds, A. R., Gassult, M. A., Wolever, M. S., Goff, D. F., Alberti, K. G. M. M. \& Hockaday, T. D. R. (1976). Lancet is, 172.

Kritchevsky, D., (1978). Am. J. clin. Nutr. 31, S65.

Morris, J. N., Marr, J. W. \&. Clayton, D. G. (1977). Br. med. J. ii, 1301.

Nilsson-Ehle, P., Garfinkel, A. S. \& Schotz, M. C. (1980). A. Rev. Biochem. 49, 667.

O'Moore, R. R., Flanagan, M., McGill, A. R., Wright, E. A., Little, C. \& Weir, D. G. (1978). Br. med. J. i, 1213. Roeschlau, P., Bernt, E. \& Gruber, W. (1974). Z. Klin. Chem. Klin. Biochem. 12, 226.

Theander, O. \& Åman, P. (1979). Swedish J. agric. Res. 9, 97.

Truswell, A. S. \& Kay, R. M. (1976). Lancet i, 367.

Tuomilehto, J., Huttunen, J., Voutilainen, E. \& Vinni, S. (1979). Vår Föda 31, suppl. 3, 217.

Wablefeld, A. W. (1974). In Methods of Enzymatic Hydrolysis, p. 1831 [H. U. Bergmayer, editor]. New York: Academic Press.

Walker, A. R. P. \& Arvidsc n, U. B. (1954). J. clin. Invest. 33, 1366. 